\title{
The integration of PBL and cooperative script to empower critical thinking skills of biology students
}

\author{
Didimus Tanah Boleng a,1, ${ }^{a}$, Elsje Theodora Maasawet a,2 \\ a Study Program of Biology Education, Faculty of Teacher Training and Education, University of Mulawarman, Jl. Kuaro Kotak, \\ City of Samarinda, East Kalimantan 75119, Indonesia \\ 1 didimus.tanahboleng@yahoo.com*; '2emaasawet@gmail.com; \\ * Corresponding author
}

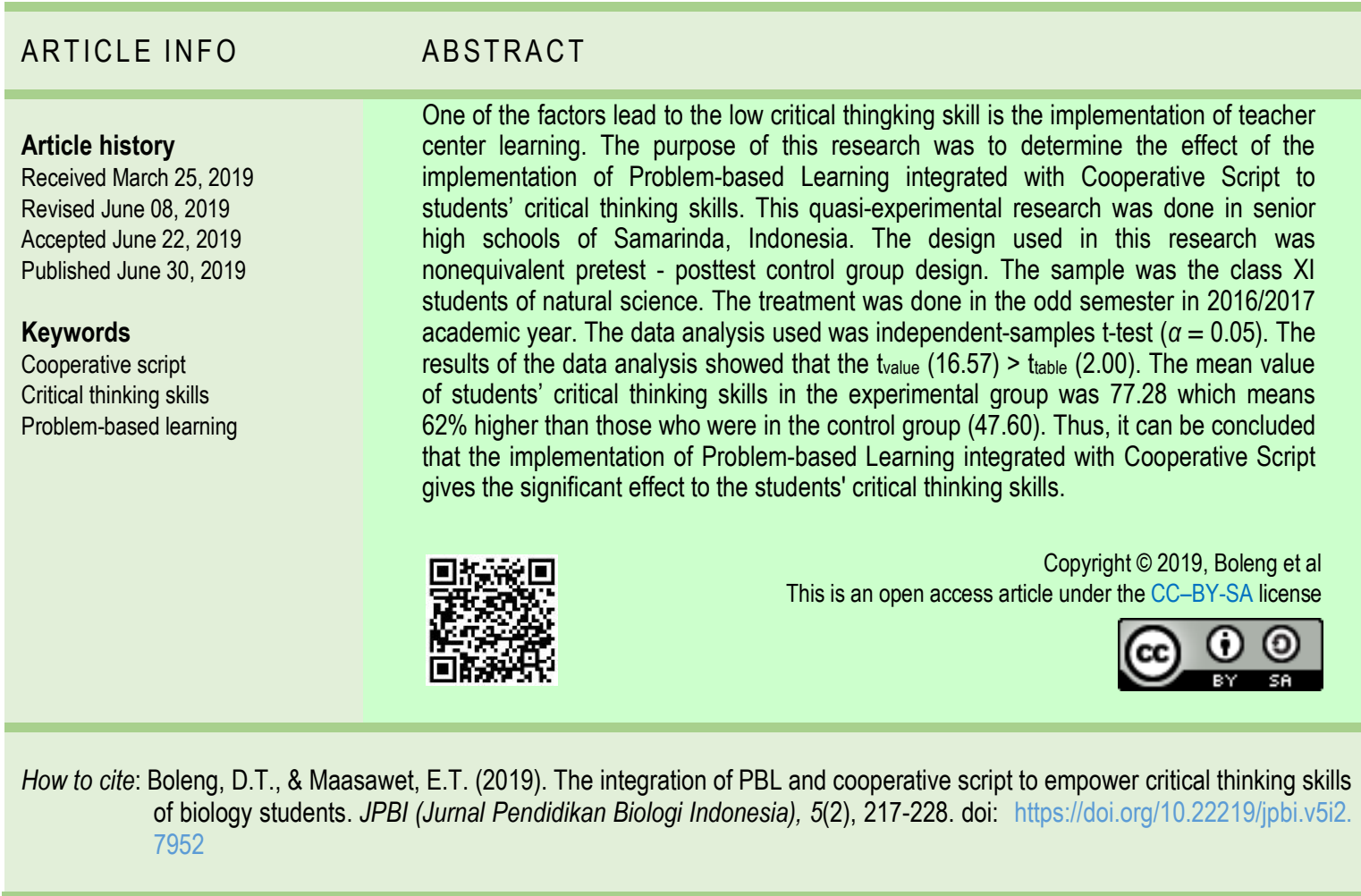

\section{INTRODUCTION}

Education or learning in the classroom has a specific learning goal. The biology learning in the $21^{\text {st }}$ century needs to pay attention to the achievement of students' critical thinking skills. By having critical thinking skills in understanding the biological concepts, the students are able to analyze problems in their lives, choose ways of solving a problem, collect data, and make a conclusion of a particular problem. Papathanasiou, Kleisiaris, Fradelos, Kakou, and Kourkouta (2014), stated that Individuals who apply critical thinking as they mature acquire knowledge and experiences and examine their beliefs under new evidence.

The biology learning in the classroom should be well designed, so that it allows the students to discover their own problems. Furthermore, the students can design ways to collect data, related to the problem solving. The students, either individually or in groups, can discuss the collected data, relate an information with the other relevant information, as an effort to solve problems. Finally, the students can make their own 
conclusions. Virginie and Miklos (2019a), stated that the students, in groups of four, will be assigned topics or problems of their choice in regard to the topic must become conversant.

The results of the interview and observations to student in $\mathrm{Xl}^{\text {th }}$ class of Natural science of Catholic senior high school of W.R. Soepratman, Samarinda city in July 2016, provided information that in the learning process, students rarely asked questions, expressed opinions, and argued based on facts. Furthermore, the results of interviews with 3 biology teachers, $100 \%$ of teachers inform that they rarely apply learning patterns that allow students to solve problems in learning. Teachers still often apply conventional learning. This situation showed that the students' critical thinking skills were not well empowered. In addition, the learning atmosphere in the classroom with biological concepts rarely engages students in discovering a problem. The learning atmosphere was mostly dominated by the lecture from the teacher. The students tended to be passive, and only recorded and heard the information from the teacher. The students rarely asked questions in the learning activities with biological concepts in the classroom.

Related to the students who rarely asked questions, expressed their opinions, collected data, discussed the incoming data and made conclusions; teachers needed to identify the causes of the phenomenon. Did the teachers fail to implement a learning model which enabled the students to ask, express their opinions, investigate, discuss the data and make inferences. The critical thinking skill of the students in class $\mathrm{XI}^{\text {th }}$ Natural Science of Catholic senior high school of W.R. Soepratman, was still low. The teachers still implemented the conventional learning, as indicated by the teachers' lecturing activities that dominated the whole learning process with biological concepts in the classroom.

The implementation of Problem-Based Learning (PBL) integrated with Cooperative Script (CS) learning model in biological concepts allowed the students to be able to find the problem. Yew and Goh (2016), stated that another review of related literature on the effect of PBL on developing nursing students 'critical thinking showed a positive relationship between the implementation of PBL as an instructional model and improvements in critical reasoning. Yusof, Hassan, Jamaludin, and Harun (2012), reported that integration of cooperative learning elements provides the needed scaffolding for developing team working skills in implementing PBL in a class consisting of small groups in a medium to large class. Furthermore, the students could search for alternative ways to solve the problems through data collection, discussing the obtained data in small group, and finally making conclusions related to the issue that had been previously formulated. After they submitted the final report and presented it in the PBL class they felt it was rewarding and could do better for the next package.

Related to the strength of PBL, Syafrudin, Darmawan, and Ridwan (2018), explain that PBL has several advantages, such as encouraging cooperation in task completion. PBL also has elements that could encourage a learning which enable the students to observe and have a dialogue with each other, so that the students can gradually understand the important role of mental activity and learning activity that occurs outside schools. The students will also be involved in the independent investigation, which allows students to interpret and explain real-world phenomena and to build understanding of the phenomenon. The students will also become independent and autonomous learners.

Cooperative learning model like CS, enables the students to summarize biological concepts that are relevant to the issues being discussed. Furthermore, in the implementation of PBL, the students are facilitated to discover and formulate problems clearly. The students have the opportunity to collect data which relevant to the problems. Furthermore, the students in small groups (twos) discuss the collected data. Finally, in groups, the students make conclusions related to the problems.

The nature and quality of critical thinking is of debates in the field. Since critical thinking has been changed to a main process in education, a common understanding of its meanings is important and necessary. Despite many definitions of critical thinking, there is not any commonly accepted definition of the concept. Most researchers define it as a kind of cognitive and problem-solving skill (Khandaghi \& Pakmehr, 2012). Critical thinking as "a way of right thinking", regards it as engagement, making decisions logically and acceptance of responsibility in what we do. Critical thinking as a high-level cognitive thinking and considers it as an ability to analyze, synthesize and evaluate. Some argue that critical thinking is manifested in skills such as evaluating current reasons and judging according to logical reasons.

Related to the system of thinking, Virginie and Miklos (2019b) explains that there are many classifications of thinking that can be found in the literature, especially in the field of education. An example is the system used by Costa and his colleagues; six R; Remembering, Repeating, Reasoning, Reorganizing, Relating, and Reflecting. 
The three high levels of Bloom's taxonomy of the educational purposes (analyzing, synthesizing, and evaluating) are often offered as a definition of critical thinking (Sunaryo, 2014). Critical thinking has been defined as an important educational goal and it is understood as reasonable reflective thinking focused on deciding what to believe or do (Herawati \& Nurhayati, 2019). Critical thinking skills are specified into six elements. The elements include: (1) determining the credibility of the source and observation, (2) summarizing and assessing deductive conclusions, (3) defining and identifying assumptions, (4) experimenting induction planning and predicting possible consequences, (5) summarizing and assessing inductive conclusions, and (6) semantics (Anders, Stellrecht, Davis, \& McCall, 2019). Puspita, Kaniawati, and Suwarma (2017), added by concluded the research that critical thinking skills need to be trained on students, and the best way to practice them is by applying active learning that facilitates students in the process of discovery of global problems.

Related to the critical thinking skills indicator studied in the study, referring to Arslan (2012) and Sari, Supana, and Suwandi (2018) that modifies the critical thinking skills indicator developed that is to be: (1) solve problems, (2) give arguments, (3) deduction, (4) induction, (5) evaluate, (6) ) Decide and implement. In order to Bailin (2002), critical thinking provides people looking at the subjects with suspicion, making interpretaion about them, deciding and teaching the learning effectively. Arslan (2012), stated that the reasons for this kind of result can be showed as disapplication of the educational activities in the way of developing some abilities of the students like critical thinking, logical thinking, inquiring etc. The most important reason of this disapplication is the inefficiency of the teachers who were educated in traditional schools in traditional ways. Moreover, the study has showed clearly that the teachers who are the applicators of the educational programmes that target critical thinking and other important values in students must be having these very features for themselves. The results of the study also have showed that all lessons are responsible for teaching the critical thinking to the students but it has been emphisized wrongly that especially the lesson of science and technology is made responsible for the such kind of abilities.

Related to the biology concepts of class XI natural science in the odd semester in accordance to 2013 curriculum, which included: cell, tissue, organ, motion system, and circulatory system (circulation). These concepts require a scientific based study in learning it. The learning phase begins with understanding the problems of the cell, tissue, organ, motion system, and circulatory system. After that, students have to determine their own ways of collecting data to be discussed as an effort to find answers to the problems that have been previously formulated. Finally, the students independently and in groups make their own conclusions to answer the problems. Concepts of cells, tissues, organs, motion systems, and circulatory system, in the discussion, related to the implementation of PBL, requires the students to summarize the concepts, which will be used in the discussion of the data obtained in small groups. Therefore, the syntaxes of CS learning model are required to discuss the collected data in the implementation of PBL, so that the whole process of scientific assessment obtain maximum results. In addition, the concepts of cells, tissues, motion system, and circulatory system is concepts which is related to the body of living things, so that the learning process with such concepts needs to be done by combining individual work (summarizing activities), and group work (the stages of scientific study).

In the levels of biological organization, the cell is the simplest concepts component which can live. In fact, there are various forms of life that are present as single-celled organisms. When arranged into a higher organizational level, such as tissue and organ, cell is the basic unit for the structure and function of organisms. Cimer and Timucin (2010), stated that the Biology course curricula determined intended student attainments under three titles, namely Science-Technology-Society-Environment Attainments (BTTÇ2), Communication Skills, Attitudes and Values (Itd.), and Scientific Research\& Scientific Process Skills (BAS). The objective of this research was to determine the effect of the implementation of PBL learning model integrated with CS learning model in the students' critical thinking skills.

The objective of research was to determine the effect of the implementation of PBL learning model integrated with CS learning model in the students' critical thinking skills.

\section{METHOD}

Research carried out by applying syntax of PBL that is integrated with CS learning model that has been developed. Syntax of PBL integrated with CS learning model, are presented in Table 1.

The type of this research is quasi-experimental. The research was conducted without making any changes to the students in the classroom. The process of the research required two equivalent classes based on statistics. One class was taught by using PBL learning model integrated with CS learning model and the other 
class was taught by using conventional learning. Conventional learning is learning that have not syntax, and does not apply PBL to combined CS.

Table 1. Syntax of PBL integrated with CS learning model

\begin{tabular}{|c|c|}
\hline Syntax & Student activity \\
\hline $\begin{array}{l}\text { Orientation problems (PBL } \\
\text { and CS) }\end{array}$ & $\begin{array}{l}\text { Students observe the description of problems related to cell, tissue, motion system, and circulatory } \\
\text { system in the student activity sheet. }\end{array}$ \\
\hline $\begin{array}{l}\text { Organizing students into } \\
\text { research (observation) (PBL) }\end{array}$ & $\begin{array}{l}\text { Students in the group formulate the problems related to concepts of cells, tissues, motion systems, } \\
\text { and circulatory systems that exist in the description of the issue, to look for ways to solve related to } \\
\text { observation or understanding the gaps in describing the problem. }\end{array}$ \\
\hline $\begin{array}{l}\text { Independent investigation in } \\
\text { a group and the group (PBL) }\end{array}$ & Students collect data for the purpose of solving the problem that has been formulated \\
\hline $\begin{array}{l}\text { Preparation of summary } \\
\text { concepts of cells, tissues, } \\
\text { motion systems, and } \\
\text { circulatory systems for } \\
\text { development (discussion) } \\
\text { related to research datal } \\
\text { observation/assessment } \\
\text { (PBL and CS) }\end{array}$ & $\begin{array}{l}\text { Students, guided by the teacher, forming a pair in the group. Student A read the summary results } \\
\text { of the cells, tissues, motion systems, and circulatory systems according to the data collected, the } \\
\text { student B listening to the summary results and correct errors in the results summary of concepts } \\
\text { related to the cell, tissue, organ system, and circulatory system. Furthermore, alternating phase, } \\
\text { students B read the results summarized related to the data collected, student A listened and } \\
\text { corrected errors student summary results relating to the concepts of cell, tissue, organ system, } \\
\text { and circulatory system. Student A and B make conclusion for pair of the student. }\end{array}$ \\
\hline Presentation (PBL) & $\begin{array}{l}\text { Pairs of students from more than half of the group in class, present the results of the discussion (is } \\
\text { discussed) for the whole class, and students from other couples respond to the results } \\
\text { presentation. }\end{array}$ \\
\hline Conclusion (PBL and CS) & $\begin{array}{l}\text { Pairs of students who do presentations conclude for all of pair of students in classroom, assisted } \\
\text { by another pair of students in the classroom, related to solving problems that have been } \\
\text { formulated. }\end{array}$ \\
\hline
\end{tabular}

The design of this research was nonequivalent pretest - posttest control group design. The subjects of the research were taken by not doing randomization in both classes. At the beginning of the research and at the end of the research, the students were given tests. The form of the test was an essay test. This research used two classes, one class as the experimental class and the other class as the control class.

This research was conducted, starting from March 2016, beginning with a survey in the location of the research (W.R. Soepratman senior high school, Samarinda city, Indonesia). After that, the quasi-experimental research was started from the beginning until the end of the odd semester in the 2016/2017 academic year (from July until November 2016). The quasi implementation of the experiment was conducted at W.R. Soepratman senior high school. The treatment of PBL learning model integrated with CS learning model was done in class $\mathrm{XI}^{\text {th }}$ Natural Science 4 (treatment class); whereas, in $\mathrm{XI}^{\text {th }}$ Natural Science 3 class applied with the conventional learning (control class). Both classes (the treatment and the control class) were tested for their equality based on the score results of their national exam in junior high school.

The population of this research was all the students of class $\mathrm{XI}^{\text {th }}$ natural science at W.R. Soepratman senior high school. The number of the parallel class of class $\left.X\right|^{\text {th }}$ Natural Science class was four classes. Those classess were class $\left.X\right|^{\text {th }}$ natural science $1,\left.X\right|^{\text {th }}$ natural science $2, X^{\text {th }}$ natural science 3 , and $\mathrm{X}^{\text {th }}$ natural science 4 . The number of the students in each class was as many as $24,17,29$, and 27 students respectively.

The samples of this research were taken by using purposive sampling. The basic considerations in the selection of the samples were: (1) the students of class $X^{\text {th }}$ Natural Science in the 2016/2017 academic year. (2) The students must attend the classes continuously throughout this research, (3) the students selected as the samples in the two classes were not correlated (independetnt sample). The classes used in this research were previously tested for the equality based on the score of science in the national examination of junior high schools. Based on the results of the equality test, class $\mathrm{X}^{\text {th }}$ Natural Science 3 and class $\mathrm{X}^{\text {th }}$ natural Science 4 were used for this research.

In relation to the data collection, the instruments used were in the forms of questionnaires and tests. The questionnaire was used to obtain information about the implementation of PBL and CS learning model, results in the form of students' critical thinking skills, and the score of the nation examination of junior high schools of the students. The instrument in the form of a test, was used to measure the critical thinking skills of the students. The tests were given before (pretest) and after (posttest) the treatments. The forms and the content of the tests in the pretest and posttest were same. The form of the tests were essay tests. The students' answers in the pretest and posttest were corrected using a scoring rubric of critical thinking skills (EL-Shaer \& Gaber, 2014). 
To determine the effect of the implementation of PBL integrated with CS learning model in empowering the critical thinking skills on biology of students, with the number of samples in both classes not the same, the results of quasi experimental research were analyzed using unpaired $t$ test (independent sample $t$ test). The process of data analysis used the assistance of the data processing program SPSS version 23.

\section{RESULTS AND DISCUSSION}

\section{The students' critical thinking skills}

The students both in the experimental and the control class, before given the treatments, were first given a pretest. After that, the treatment was given (the experimental class was treated by using problem-based learning integrated with CS learning model), the control class was taught by using conventional learning, during the odd semester of 2016/2016 academic year. At the end of the research, the students in both classes were given the posttest. The score of the pretest and posttest for the students' critical thinking skills in the experimental class and the control class, are presented in Table 2 and Table 3.

Table 2. Score of pretest of students' critical thinking skills of X| ${ }^{\text {th }}$ class in the experimental and the control classes

\begin{tabular}{|c|c|c|c|c|}
\hline \multirow[t]{2}{*}{ No. } & \multicolumn{2}{|c|}{ Experimental Class } & \multicolumn{2}{|c|}{ Control Class } \\
\hline & Initial of Student's Name & Score & Student's Name & Score \\
\hline 1. & $\mathrm{MC}$ & 12.5 & EF & 17.5 \\
\hline 2. & BFF & 17.5 & IA & 10 \\
\hline 3. & ST & 12.5 & CMS & 17.5 \\
\hline 4. & GMR & 10 & GC & 12.5 \\
\hline 5. & NT & 17.5 & CC & 17.5 \\
\hline 6. & YCH & 10 & GSS & 10 \\
\hline 7. & GG & 17.5 & CA & 10 \\
\hline 8. & GSS & 5 & AL & 12.5 \\
\hline 9. & ARS & 10 & ESJ & 17.5 \\
\hline 10. & $\mathrm{E}$ & 10 & VV & 17.5 \\
\hline 11. & HRS & 20 & $\mathrm{MH}$ & 12.5 \\
\hline 12. & BKP & 20 & JGGS & 10 \\
\hline 13. & YO & 7.5 & YAK & 10 \\
\hline 14. & FR & 20 & LC & 17.5 \\
\hline 15. & KHST & 17.5 & NY & 12.5 \\
\hline 16. & SSM & 10 & GA & 10 \\
\hline 17. & Y & 17.5 & $\mathrm{AMH}$ & 12.5 \\
\hline 18. & VRL & 17.5 & $\mathrm{Ml}$ & 12.5 \\
\hline 19. & TDLW & 7.5 & RTW & 5 \\
\hline 20. & JLA & 10 & AF & 10 \\
\hline 21. & ATK & 20 & $\mathrm{FM}$ & 17.5 \\
\hline 22. & $\mathrm{ORH}$ & 20 & VEP & 17.5 \\
\hline 23. & SDR & 10 & $C X$ & 12 \\
\hline 24. & CYD & 7.5 & RSGR & 17.5 \\
\hline 25. & B & 12.5 & $\mathrm{NC}$ & 12 \\
\hline 26. & SAHS & 15 & NHL & 20 \\
\hline 27. & AlO & 15 & AK & 10 \\
\hline 28. & & & $N G$ & 17.5 \\
\hline 29. & & & MA & 10 \\
\hline
\end{tabular}

Although critical thinking skill can be improved via curriculum (Khandaghi \& Pakmehr, 2012). Major and Mulvihill (2018), stated that Problem-based learning (PBL) is a constructivist approach that stresses learning through experiential problem solving. Furthermore, it has been described as a method of instruction that develops learners' knowledge and problem-solving skills through real-world problems. Problem-based learning is both problems centered and learner centered in a dynamic process whereby students are actively involved in posing and solving problems related to the content and context under investigation. Students are no longer passive learners, but active participants in their learning. This has been supported who stated that educational research demonstrates that active learning is the most effective technique for students to learn, apply, integrate, and retain information. 
The complexity and array of operationalized definitions or descriptions affiliated with the topic of problembased learning, and submits that characteristics of PBL identify clearly (1) the role of the tutor as a facilitator of learning, (2) the responsibilities of the learners to be self-directed and self-regulated in their learning, and (3) the essential elements in the design of ill-structured instructional problems as the driving force for inquiry. Many others have written about PBL in compelling ways. These educators have researched the application of PBL across curriculum and content areas such as realms of both hard and soft sciences, medical school curricula, and business administration programs. Their collective voice recognizes the importance of problembased learning as a constructivist instructional model based on authentic problem-solving experience in which all aspects of the project are anchored by a larger task.

Table 3. The score of the posttest of the students' critical thinking skills in $\mathrm{XI}^{\text {th }}$ class in the treatment and the control classes

\begin{tabular}{|c|c|c|c|c|}
\hline No. & Experimental Class & & Control Class & \\
\hline & Initial of Student's Name & Score & Student's Name & Score \\
\hline 1. & MC & 75 & $\mathrm{EF}$ & 47.5 \\
\hline 2. & BFF & 80 & $\mathrm{IA}$ & 47.5 \\
\hline 3. & ST & 65 & CMS & 57.5 \\
\hline 4. & GMR & 75 & GC & 52.5 \\
\hline 5. & NT & 75 & $\mathrm{CC}$ & 47.5 \\
\hline 6. & $\mathrm{YCH}$ & 67.5 & GSS & 50 \\
\hline 7. & GG & 67.5 & $\mathrm{CA}$ & 47.5 \\
\hline 8. & GSS & 75 & $\mathrm{AL}$ & 42.5 \\
\hline 9. & ARS & 89 & ESJ & 47.5 \\
\hline 10. & $E$ & 80 & VV & 47.5 \\
\hline 11. & HRS & 82.5 & $\mathrm{MH}$ & 45 \\
\hline 12. & BKP & 82.5 & JGGS & 47.5 \\
\hline 13. & YO & 87.5 & YAK & 45 \\
\hline 14. & FR & 67.5 & LC & 47.5 \\
\hline 15. & KHST & 82.5 & NY & 45 \\
\hline 16. & SSM & 80 & $\mathrm{GA}$ & 45 \\
\hline 17. & $Y$ & 72.5 & $\mathrm{AMH}$ & 45 \\
\hline 18. & VRL & 82.5 & MI & 45 \\
\hline 19. & TDLW & 82.5 & RTW & 50 \\
\hline 20. & JLA & 75 & $\mathrm{AF}$ & 45 \\
\hline 21. & ATK & 75 & FM & 45 \\
\hline 22. & $\mathrm{ORH}$ & 80 & VEP & 60 \\
\hline 23. & SDR & 75 & $C X$ & 55 \\
\hline 24. & CYD & 82.5 & RSGR & 60 \\
\hline 25. & B & 75 & $\mathrm{NC}$ & 67.5 \\
\hline 26. & SAHS & 80 & $\mathrm{NHL}$ & 32.5 \\
\hline 27. & $\mathrm{AlO}$ & 75 & AK & 32.5 \\
\hline 28. & & & $N G$ & 42.5 \\
\hline 29. & & & MA & 52.5 \\
\hline
\end{tabular}

The average score of the students' critical thinking skill was different at the pretest and posttest, both in the experimental and in the control class. The difference in the average score of the students' critical thinking skills happened after the two classes were given different treatments. Figure 1 shows the difference in the average score of students' critical thinking skills in the pretest and posttest on the experimental class and control class.

Based on the results of the data analysis, it was obtained that, in relation to the critical thinking skills, the value of $t_{\text {count }}$ was -16.57 . Value of $t_{\text {table }}(d f=54),(\alpha=0.05 ; 1 / 2 a=0.025)$ was 2.00 . Thus, based on the pattern of two-party test, it is known that the position of the value of $t_{\text {count }}$ with $t_{\text {table }} t_{\text {is }} t_{\text {count }}<t_{\text {table }}(-16.56<2.00)$. Based on the principle of decision making for the two-party test, the position of $t_{\text {count }}$ and $t_{\text {table, }}$ shows that the null hypothesis was rejected, and the alternative hypothesis was accepted. The acceptance of the alternative hypothesis means that there was a significant effect of the implementation of PBL learning model integrated with CS learning model on the students' critical thinking skills. 


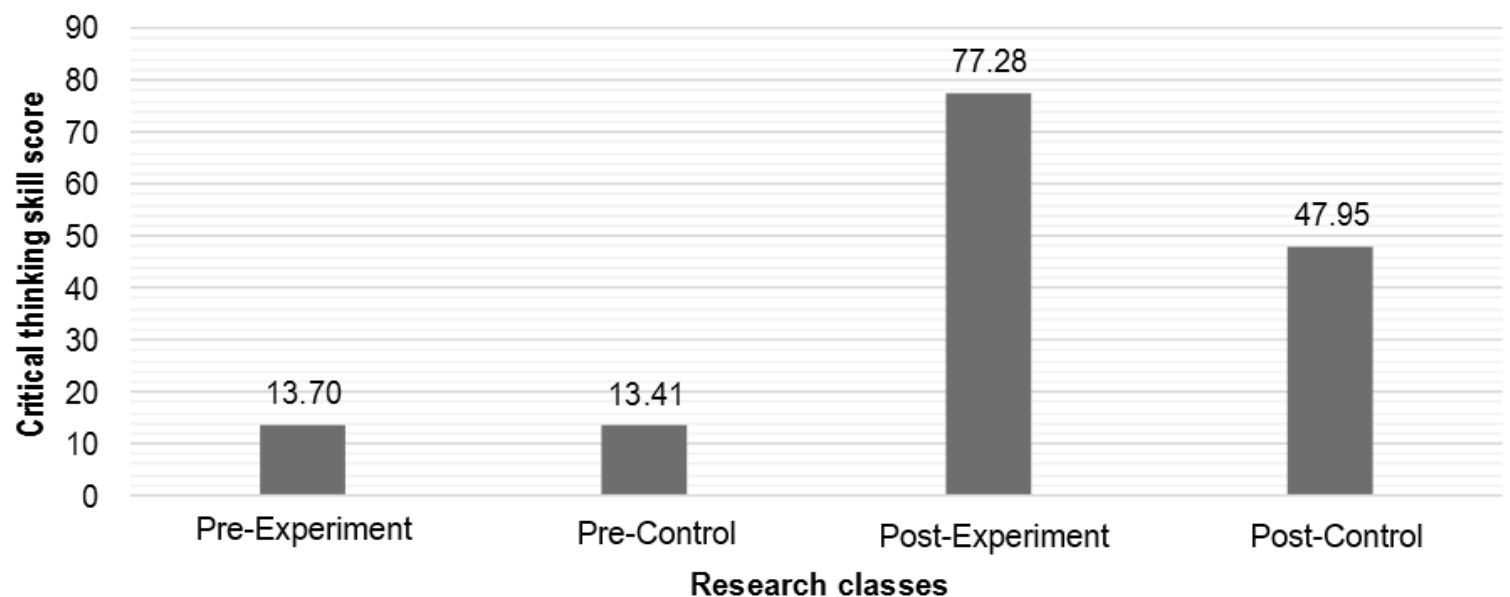

Figure 1. The average score of the students' critical thinking skills in the pretest and posttest

Relation to the average score of the students' critical thinking skills and the percentage of the increase from the pretest to post test, it was known that in the treatment classes was as much as $77.28,0.62$ higher than that of the students in the control class (47.60). Meanwhile, the percentage of the increase score in the pretest to posttest, it is known that in the experimental class, the highest percentage increase was $1.400 \%$, and the lowest increase was $237.5 \%$; while in the control class, the highest percentage increase was $900 \%$, and the lowest increase was $62.5 \%$.

The learning activity in the classroom on biology concepts designed by teachers, should enable the students to be actively involved both individually and in groups. The pattern of the learning activities should be directed to the science process done by the students. The students are invited to get involved in designing the stages of the scientific process to solve problems which were found by the students themselves. Thus, the students are challenged with the ways of problem solving that they chose.

The results of the observation showed that the implementation of PBL integrated with CS learning model allowed the students, individually and in groups, to try to understand the description of the problems. For examples of problems description in PBL with matter about cell organisms are: We need to know the various organisms around us. Thus, we can control beneficial organisms and harmful organisms (das sollen). Unicellular organisms, like bacteria, our eyes cannot observe them, we need help with a magnifying device to help our eyes to observe these unicellular organisms (das sein). Unicellular organisms cannot be observed by humans using the naked eye (Gap). How are human efforts to observe unicellular organisms? (Problem). After that, the students attempted to formulate the problems as a basis to conduct an investigation. The application of PBL is combined with CS, allowing students to summarize the material individually first. With the help of student summary results (CS), it helps students discuss material (investigation data) at the association stage according to the 5M pattern (curriculum 2013) and can also be facilitated by PBL syntax (data collection). The working pattern of students is like this, as expected in the 2013 curriculum implementation, which expects students to experience learning in the 5M pattern, which is facilitated by PBL syntax combined with CS.

Relation to the formulation of the problem, the students were continuously trained to make questions related to the theme (concepts) of biology being discussed. If students are well trained, they will have the skills to produce questions using good, logical and understandable language, to guide them in conducting investigations. Therefore, in the implementation of PBL integrated with CS learning model, when there are some obstacles in the initial meetings in the classroom, teachers need to make an improvement in the learning process. The improvement steps that teachers can begin reflection activity to find the factors that hinder the implementation of the stages of PBL integrated with CS learning model. Thus, at the subsequent meetings, the implementation of learning model which implements the learning patterns can be better and more effective. Usman (2019), reported that the students were provided with a long list of resources to help them work on the problems.

The student learning activities, especially in understanding the problems, need to be continuously developed by the teachers. Students must be accompanied and helped, if they find some difficulties in learning. Teachers need to continuously identify the problems that the students encounter on each stage of 
PBL learning. In addition, teachers also need to understand the implementation and the meaning of the syntaxes of CS learning model. Thus, the implementation of the stages of PBL integrated with CS learning model is able to empower the critical thinking skills of biology students. Balan, Yuen, and Mehrtash, (2019) stated that the challenge for the teacher is the need to provide individual guidance for several concurrent projects at a time.

Relation to the students who are less active in the implementation of PBL integrated with CS learning model, teachers need to continuously motivate the students work actively, both individually and in groups. The activities that teachers can do are to always monitor the process and the results of the students' work either individually or in groups. Thus, the obstacles in the implementation of PBL integrated with CS learning model, as well as the results of students' activities can be monitored and improved.

The results of the data analysis showed in the Analysis Data section that there was a significant effect of the implementation of PBL integrated with CS learning model on the students' critical thinking skills. The results of the research showed that implementation of PBL integrated with CS learning model activates the students to think in solving the problems of learning. Chan and Blikstein (2018), and Usman (2019), explained in his health research that the ability to identify and define health problems, and search for information to resolve or manage these problems and given a health problem. The learning process in class, students need to be guided by the teacher so that students can think about material related to cells and tissues. Thus, students are challenged to find alternative solutions to these problems. To facilitate student activities in PBL, schools are expected to prepare learning facilities and infrastructure, such as biology laboratories, which facilitate students in finding information related to efforts to solve problems in learning.

Mahanal, Avila, and Zubaidah (2018), adds that PBL has some advantages, such as encouraging cooperation in completing the task. PBL syntaxes are combined with CS, allowing students to be able to construct problem statements to guide them to conduct investigations (data collection), and discuss data obtained by first summarizing the cell material of an organism. Problem-Based Learning also has the elements apprentice learning which can encourage observation and dialogue with others people, so that the students can gradually understand the important role of mental activity and learning that occurs outside schools. Students will also be involved in the investigation of their own choices, which allows them to interpret and explain real-world phenomena and build understanding of the phenomenon. Students will also be an independent and autonomous learner. Related to integrated CS learning model to PBL, Chen and Kuo (2019), explain that one of the effective ways is to ask students to write a one-sentence summary after reading each paragraph. Another way is to ask students to create a summary that is intended to help other students learn the concepts, in part because these activities force the summary to be concise and to seriously consider which parts are important.

Figure 1 showed that the average of the students' critical thinking skills who were taught by PBL integrated with CS learning model was higher than that of the students in the control class. PBL syntaxes are combined with CS, allowing students to be able to construct problem statements to guide them to carry out investigations (data collection) about cells, which can be done with the help of a microscope in the laboratory, and discuss data obtained by first summarizing cell organism material. PBL syntaxes are combined with CS, allowing students to be able to construct problem statements to guide them to carry out investigations (data collection) about cells, which can be done with the help of a microscope in the laboratory, and discuss data obtained by first summarizing cell organism material. This information is consistent with the findings of the research Birgili (2015), that the PBL approach is more effective than the traditional learning techniques. Rodzalan and Saat (2015), add that the results of his research revealed that students become better at making criticisms, developing their own positions, and making decision because both thinking skills, namely critical thinking skill and creative thinking skill have been implemented in the teaching and learning process. We have to agree that, first, we have to analyze the problems, then one has to generate possible solutions, the next one must select and implement the best solution, and finally, one must evaluate the effectiveness of the solution.

The implementation of PBL learning allowed the students to perform the activity in accordance with the scientific process. Students had the opportunity to learn to observe an object or a problem provided by the teacher. Individually or in groups, the students learned to observe objects or descriptions of problems in biology. The students were also trying to ask about the problems. Yusof et al (2012), stated that considered the most complex of all intellectual functions, problem solving has been defined as higher-order cognitive process that requires certain pedagogical ways to improve. 
In addition, the implementation of the stages of PBL learning integrated with CS learning model allowed the students to ask questions on biological objects which were observed. The students were induced to ask questions, related to the observed object or a description of the problem, to proceed with the investigation (data collecting) associated with the problem solving that has been formulated. Associated with a person's critical thinking skills, Redhana and Liliasari (2008), and Zori (2016), explain that the critical thinking skill is the ability of a person to make decisions that can be relied on that affect a person's life. Critical thinking skills are also a critical inquiry, so that a person who think critically would investigate the problems, ask questions, propose new answers that challenge the status quo, discover new information that is against to dogma and doctrine. In addition, critical thinking skill is very important to be mastered, so that we can avoid fraud, indoctrination and brainwashing (mind washing).

Related to biological material discussed in research, namely about: cells, tissues, organs, motion systems, and circulatory systems; in the discussion, efforts are needed according to the scientific process supported by a summary of the material made by students. Students are guided by the teacher to formulate problems related to: cells, tissues, organs, motion systems, and circulatory systems. Students can choose how to collect data according to the need to solve the problem (data collection can be done through observation in the laboratory using a microscope or other assistive devices, source books, journals, and the internet). Students, independently, are guided to make summaries of material about cells, tissues, organs, organ systems, and circulatory systems; needed to discuss the data obtained. Furthermore, students, in the guidance of the teacher, make conclusions about solving problems that have been set. Finally, students in groups present their findings to other students.

Related to efforts to empower critical thinking skills, in his research that improving students' critical thinking skills through the teaching and learning by using inquiry-based learning activities using social networks and cloud computing suitable for the application of real practice in helping students develop their knowledge and skills (Herawati \& Nurhayati, 2019; Nurkhaliza, Hamid, \& Suharto, 2018). Warouw (2010) adds that CS learning strategy has some advantages, besides theoretically it is also a learning model that develops collaborative efforts in achieving common goals. Furthermore, it is explained that the related reference on CS learning strategy has not given a comprehensive explanation on the empowerment of metacognitive skills for learning. One of the benefits of CS learning is an agreement between students and students, teachers and students, collaboratively to solve problems in learning. This strategy may be more effective if it is integrated with metacognitive strategies in its syntaxes. In addition, EL-Shaer and Gaber (2014), concluded in his research that, statistically, there is a significant improvement in students' critical thinking after they were treated with PBL compared to that before the intervention. This shows that awareness of critical thinking is steadily increasing (İşlek \& Hürsen, 2014).

The implementation of the syntaxes of PBL learning enabled the students to be able to do an investigation (data collecting). The students collected the data in accordance with the formulation of the problems that had been made. The data collection activity enabled the students to have experience on how, how much, how the relationship of data with the problems of research. The experience of collecting data made the students not only received information from the other parties, but the students were also trained to find their own power that they wanted. Reyes (2017), explained that one advantage of PBL is authentic investigative activities.

Moreover, the implementation of the syntaxes of PBL learning enabled the students to make conclusions based on the collected data. The conclusion can be made in groups, or in large groups, including the entire class after the presentation process (communicate). Wilde-Larsson et al (2018), also reported the results of her research that in general, the critical thinking skill of the students in the experimental class had a good increase. The increased critical thinking skill on the sub-indicator of making and considering decision on the experimental class which was quite high indicated that the students' ability in the experimental class in explaining the background of a fact, identifying the consequences of a solution, and proposing alternative solutions had developed well after they were taught by using science learning integrated PBL learning model.

Conventional learning in the control class, gives a lower average score compared to the application of PBL combined with CS in the treatment class, in empowering critical thinking skills. The practice of students is very lacking in learning to formulate problems, find ways to solve problems, collect data, conduct discussions about the data obtained, and learn to draw conclusions. Arslan (2012), stated that the reasons for this kind of result can be showed as disapplication of the educational activities in the way of developing some abilities of the students like critical thinking, logical thinking, inquiring etc. Botelho, Lam, Watt, Leung, and Kember (2018), and Nazarenko (2015), stated that our program was designed not to replace conventional learning with virtual training, but rather use a blended approach to improve the midwifery skills of students. 


\section{CONCLUSION}

Based on the results of data analysis and the discussion, it can be concluded that implementation the integration of PBL and CS is able to empower critical thinking skills in biology of senior high school students. In relation to the conclusion of the research, it is suggested that the biology teachers of senior high Schools select and implement PBL integrated with CS learning model in the discussion of biological concepts, as an effort to empower students' critical thinking skills.

\section{ACKNOWLEDGEMENT}

We thank the project managers of the project of Research Program Development and Community-Based Research and Technology Education Quality Improvement 2016, Faculty of Teacher Training and Education, University of Mulawarman, Indonesia, with a number of research contracts: 2190 / UN17.5 /KP/ 2016, dated: October 3, 2016, for the funding of this research.

\section{REFERENCES}

Anders, P. L., Stellrecht, E. M., Davis, E. L., \& McCall, W. D. (2019). A systematic review of critical thinking instruments for use in dental education. Journal of Dental Education, 83(3), 1-10. doi: https://doi.org/10. 21815/JDE.019.043

Arslan, S. (2012). The influence of environment education on critical thinking and environmental attitude. Procedia-Social and Behavioral Sciences, 55, 902-909. doi: https://doi.org/10.1016/j.sbspro.2012.09.5 79

Bailin, S. (2002). Critical thinking and science education. Science \& Education, 11(4), 361-375. Retrieved from https://link.springer.com/article/10.1023/A:1016042608621

Balan, L., Yuen, T., \& Mehrtash, M. (2019). Problem-based learning strategy for CAD software using freechoice and open-ended group projects. Procedia Manufacturing, 32, 339-347. doi: https://doi.org/10. 1016/j.promfg.2019.02.223

Birgili, B. (2015). Creative and critical thinking skills in problem-based learning environments. Journal of Gifted Education and Creativity, 2(2), 71-80. Retrieved from https://eric.ed.gov/?id=ED563985

Botelho, M. G., Lam, O. L. T., Watt, R. M., Leung, D. Y. P., \& Kember, D. (2018). Evaluation of peer-generated MCQs to assess and support learning in a problem-based learning programme. European Journal of Dental Education, 22(3), 358-363. doi: https://doi.org/10.1111/eje.12304

Chan, M. M., \& Blikstein, P. (2018). Exploring problem-based learning for middle school design and engineering education in digital fabrication laboratories. Interdisciplinary Journal of Problem-Based Learning, 12(2), 1-12. doi: https://doi.org/10.7771/1541-5015.1746

Chen, C. M., \& Kuo, C. H. (2019). An optimized group formation scheme to promote collaborative problembased learning. Computers \& Education, 133, 94-115. doi: https://doi.org/10.1016/j.compedu.2019.01. 011

Cimer, A., \& Timucin, M. (2010). Content of an in-service training to develop and assess activities minding critical thinking. Procedia-Social and Behavioral Sciences, 9, 958-962. doi: https://doi.org/10.1016/j. sbspro.2010.12.267

EL-Shaer, A., \& Gaber, H. (2014). Impact of problem-based learning on students' critical thinking dispositions, knowledge acquisition and retention. Journal of Education and Practice, 5(14), 74-85. Retrieved from https://www.iliste.org/Journals/index.php/JEP/article/view/12992

Herawati, L., \& Nurhayati, E. (2019). Eksperimentasi model pembelajaran cooperative script untuk melatih kecakapan akademik siswa. MOSHARAFA Jurnal Pendidikan Matematika, 8(1), 1-10. Retrieved from https://journal.institutpendidikan.ac.id/index.php/mosharafa/article/view/mv8n1_12

Isşlek, D., \& Hürsen, Ç. (2014). Evaluation of critical thinking studies in terms of content analysis. ProcediaSocial and Behavioral Sciences, 131, 290-299. doi: https://doi.org/10.1016/j.sbspro.2014.04.119

Khandaghi, M. A., \& Pakmehr, H. (2012). Critical thinking disposition: A neglected loop of humanities curriculum in higher education. Cypriot Journal of Educational Sciences, 7(1), 1-13. Retrieved from https://profdoc.um.ac.ir/paper-abstract-1027268.html

Mahanal, S., Avila, S., \& Zubaidah, S. (2018). Potensi model pembelajaran biologi berbasis reading-concept map cooperative script (REMAP-CS) dan gender terhadap keterampilan berpikir kritis siswa SMA kota 
Malang. Prosiding Seminar Nasional Pendidikan Biologi, 1-10. Retrieved from http://www.jurnalfkip.unram.ac.id/index.php/SemnasBIO/article/view/695

Major, T., \& Mulvihill, T. M. (2018). Problem-based learning pedagogies in teacher education: The case of Botswana. Interdisciplinary Journal of Problem-Based Learning, 12(1), 1-11. doi: https://doi.org/10. 7771/1541-5015.1543

Nazarenko, A. L. (2015). Blended learning vs traditional learning: What works?(a case study research). Procedia-Social and Behavioral Sciences, 200, 77-82. doi: https://doi.org/10.1016/j.sbspro.2015.08.018

Nurkhaliza, G. N., Hamid, A., \& Suharto, B. (2018). Meningkatkan berpikir kritis melalui model cooperative script dikolaborasi dengan model think pair share (TPS) berbantuan LKPD level representasi kimia materi larutan penyangga. Journal of Chemistry and Education (JCAE), 2(1), 1-10. Retrieved from http://fkg.jtam.unlam.ac.id/index.php/jcae/article/view/113

Papathanasiou, I. V., Kleisiaris, C. F., Fradelos, E. C., Kakou, K., \& Kourkouta, L. (2014). Critical thinking: the development of an essential skill for nursing students. Acta Informatica Medica (Journal of Academy of Medical Sciences of Bosnia and Herzegovina, 22(4), 283-286. doi: https://doi.org/10.5455/aim.2014. 22.283-286

Puspita, I., Kaniawati, I., \& Suwarma, I. R. (2017). Analysis of critical thinking skills on the topic of static fluid. Journal of Physics: Conference Series, 895(1), 1-5. doi: https://doi.org/10.1088/1742-6596/895/1/012 100

Redhana, I. W., \& Liliasari. (2008). Program pembelajaran keterampilan berpikir kritis pada topik laju reaksi untuk siswa SMA. Jurnal Forum Kependidikan, 27(2), 103-112. Retrieved from http://forumkepen didikan.unsri.ac.id/userfiles/Artikel I Wayan Redhana-Liliasari UPG\&UPI \%280K\%29-ok-nian.pdf

Reyes, E. C. (2017). Infusion of the critical thinking in chemistry through selected teaching strategies. JPAIR Multidisciplinary Research, 29(1), 1-10. doi: https://doi.org/10.7719/jpair.v29i1.517

Rodzalan, S. A., \& Saat, M. M. (2015). The perception of critical thinking and problem solving skill among Malaysian undergraduate students. Procedia-Social and Behavioral Sciences, 172, 725-732. https://doi. org/10.1016/j.sbspro.2015.01.425

Sari, F., Supana, \& Suwandi, S. (2018). Problem based learning model assisted edmodo. Proceedings of the 1st International Conference on Education Innovation (ICEI 2017), 173, 112-116. doi: https://doi. org/10.2991/icei-17.2018.30

Sunaryo, Y. (2014). Model pembelajaran berbasis masalah untuk meningkatkan kemampuan berpikir kritis dan kreatif matematik siswa SMA di kota Tasikmalaya. Jurnal Pendidikan Dan Keguruan, 1(2), 41-51. Retrieved from https://media.neliti.com/media/publications/209679-model-pembelajaran-berbasis-masa lah-untu.pdf

Syafrudin, U., Darmawan, D., \& Ridwan, I. R. (2018). Penerapan model cooperative script dalam pembelajaran PKn untuk meningkatkan hasil belajar siswa pada konsep bangga sebagai anak Indonesia. AR-RIAYAH Jurnal Pendidikan Dasar, 2(2), 1-8. doi: https://doi.org/10.29240/jpd.v2i2.661

Usman, R. (2019). Upaya meningkatkan hasil belajar ekonomi pada materi pendapatan nasional dengan menggunakan metode cooperative script pada siswa kelas x IPS MAN Nagekeo tahun pelajaran 2018/2019. Jurnal IImiah Mandala Education, 5(1), 1-12. Retrieved from http://ejournal.mandalanursa. org/index.php/JIME/article/view/686

Virginie, F. C., \& Miklos, S. (2019a). Fifty years on: A retrospective on the world's first problem-based learning programme at McMaster University Medical School. Health Professions Education, 5(1), 3-12. doi: https://doi.org/10.1016/j.hpe.2018.04.002

Virginie, F. C., \& Miklos, S. (2019b). Problem solving skills versus knowledge acquisition: the historical dispute that split problem-based learning into two camps. Advances in Health Sciences Education, 24(3), 619635. doi: https://doi.org/10.1007/s10459-018-9835-0

Warouw, Z. W. M. (2010). Pembelajaran cooperative script metakognitif (CSM) yang memberdayakan keterampilan metakognitif dan hasil belajar siswa. Seminar Nasional Pendidikan Biologi FKIP UNS 2010, 188-199. Retrieved from https://jurnal.fkip.uns.ac.id/index.php/prosbio/article/view/1258

Wilde-Larsson, B., Aiyub, I., Hermansyah, H., Hov, R., Hoye, S., Gillund, M. V., ... Nordstrom, G. (2018). Critical thinking, research utilization and barriers to this among nursing students in Scandinavia and Indonesia. Nordic Journal of Nursing Research, 38(1), 1-10. doi: https://doi.org/10.1177/20571585177 04398

Yew, E. H. J., \& Goh, K. (2016). Problem-based learning: An overview of its process and impact on learning. Health Professions Education, 2(2), 75-79. https://doi.org/10.1016/j.hpe.2016.01.004 
Yusof, K. M., Hassan, S. A. H. S. H., Jamaludin, M. Z., \& Harun, N. F. (2012). Cooperative problem-based learning (CPBL): Framework for integrating cooperative learning and problem-based learning. ProcediaSocial and Behavioral Sciences, 56, 223-232. doi: https://doi.org/10.1016/j.sbspro.2012.09.649

Zori, S. (2016). Teaching critical thinking using reflective journaling in a nursing fellowship program. The Journal of Continuing Education in Nursing, 47(7), 321-329. doi: https://doi.org/10.3928/00220124-20 160616-09 